Article

\title{
Farmers' Knowledge and Management Practices of Fall Armyworm, Spodoptera frugiperda (J.E. Smith) in Benin, West Africa
}

\author{
Sidol Houngbo ${ }^{1}{ }^{\mathbb{D}}$, Afio Zannou ${ }^{1, *}$, Augustin Aoudji ${ }^{1}$, Hervé C. Sossou ${ }^{2}$, Antonio Sinzogan ${ }^{1}$, \\ Rachidatou Sikirou ${ }^{2}$, Espérance Zossou ${ }^{1}$, Henri S. Totin Vodounon ${ }^{3}$, Aristide Adomou ${ }^{4}$ and \\ Adam Ahanchédé ${ }^{1}$ \\ 1 Faculté des Sciences Agronomiques (FSA), Université d'Abomey-Calavi, 01 BP 526 Cotonou, Benin; \\ houngbo.sidol@gmail.com (S.H.); augustin.aoudji@gmail.com (A.A.); sinzogan2001@yahoo.fr (A.S.); \\ esperancezossou@gmail.com (E.Z.); ahanchedeadam@yahoo.fr (A.A.) \\ 2 Institut National des Recherches Agricoles du Bénin (INRAB), 01 BP 884 Cotonou, Benin; \\ sossou7@yahoo.fr (H.C.S.); rachidatous@yahoo.fr (R.S.) \\ 3 Institut de Géographie, de l'Aménagement du Territoire et de l'Environnement (IGATE), Université \\ d'Abomey-Calavi, 01 BP 526 Cotonou, Benin; totinsourouhv@gmail.com \\ 4 Faculté des Sciences et Techniques (FAST), Université d'Abomey-Calavi, 01 BP 526 Cotonou, Benin; \\ adomou.a@gmail.com \\ * Correspondence: zannou.afio@gmail.com; Tel.: +229-97449255
}

Received: 29 August 2020; Accepted: 21 September 2020; Published: 25 September 2020

check for updates

\begin{abstract}
Spodoptera frugiperda has caused significant losses of farmer income in sub-Saharan countries since 2016. This study assessed farmers' knowledge of S. frugiperda, their perceptions and management practices in Benin. Data were collected through a national survey of 1237 maize farmers. Ninety-one point eight percent of farmers recognized S. frugiperda damage, $78.9 \%$ of them were able to identify its larvae, and $93.9 \%$ of the maize fields were infested. According to farmers, the perceived yield losses amounted to $797.2 \mathrm{~kg} / \mathrm{ha}$ of maize, representing $49 \%$ of the average maize yield commonly obtained by farmers. Chi-square tests revealed that the severity of the pest attacks was significantly associated with cropping practices and types of grown maize varieties. About $16 \%$ of farmers identified francolin (Francolinus bicalcaratus), village weaver (Ploceus cucullatus), and common wasp (Vespula vulgaris) as natural enemies and $5 \%$ of them identified yellow nutsedge, chan, shea tree, neem, tamarind, and soybean as repellent plants of S. frugiperda. Most farmers (91.4\%) used synthetic pesticides and $1.9 \%$ of them used botanical pesticides, which they found more effective than synthetic pesticides. Significant relationships exist between farmers' management practices, their knowledge, organization membership, and contact with research and extension services. More research is required to further understand the effectiveness of botanical pesticides made by farmers against $S$. frugiperda and to refine them for scaling-up.
\end{abstract}

Keywords: Spodoptera frugiperda; farmers' knowledge; perception; pest management practices; maize yield losses; damage severity; fall armyworm

\section{Introduction}

The fall armyworm, Spodoptera frugiperda (J.E. Smith) (Lepidoptera: Noctuidae), once considered endemic to North and South America, has become an invasive pest in Africa [1]. It was detected for the first time in Sao Tome and Principe, Nigeria, Benin, and Togo in 2016 [2]. To date, the presence of S. frugiperda has been reported in more than 30 sub-Saharan countries [3,4]. It has been documented to feed on 353 host plants belonging to 76 plant families, mainly Poaceae, Asteraceae, and Fabaceae [5]. 
In the absence of proper management methods, $S$. frugiperda has the potential to cause maize yield losses of 8.3 to 20.6 million metric tons per year in 12 of Africa's maize producing countries, which represents a range of 21 to $53 \%$ of the annual production of maize [4]. The value of these losses ranged from US\$ 2.48 billion and US\$ 6.19 billion [4]. In Benin, S. frugiperda attacks mainly maize crops [6]. Surveys carried out in 2016 by the Ministry of Agriculture, Livestock, and Fisheries of Benin revealed that over 395,000 ha of maize were damaged, resulting in a loss of 415,000 tons, or $30 \%$ of national production [6]. Therefore, it represents a threat to the country's food security and economy.

The main management methods used in America against S. frugiperda are synthetic pesticides and genetically modified crop varieties [7]. Several studies have indicated that $S$. frugiperda is resistant to several insecticides such as pyrethroids, organophosphorus, and carbamates [8,9]. In addition, recent studies have shown resistance of $S$. frugiperda to several genetically modified varieties of maize such as MON89034, TC1507, and NK603 [10-13]. Therefore, alternative methods that reduce the application of synthetic pesticides and that use botanicals and natural enemies are recommended in Africa [1,4]. Information on farmers' knowledge and management practices are essential for developing appropriate management methods suited to farmers' need [14-16]. Farmers develop knowledge and management practices and have their own ideas on how to solve a given problem in the practical and economical ways [17]. One of the main barriers to implementing a pest management program has been shown to be the lack of information about farmers' knowledge, perceptions, and management practices [18].

In the literature, two complementary approaches to the development and extension of technologies are known: conventional and participatory approaches. Some critics to conventional approach viewed it as a linear process of practical application of scientific knowledge [19], where farmers' knowledge could be overlooked in the development of technologies [20]. African farmers are well-known as innovators and experimenters [21]. The participatory approach addresses the limits of the conventional approach by considering farmers' knowledge and involving farmers in the process of development and extension of technologies [22,23].

In this study, knowledge refers to what farmers know about the biology and ecology of $S$. frugiperda. Perception refers to how farmers perceive S. frugiperda attacks, the damage caused by this pest, and the effectiveness of the management practices they use. The identification of pests and the quantification of their damage by farmers could be quite different and less accurate than that of a trained expert. Nevertheless, they provide crucial information, as farmers make decisions based on what they think is the problem [24]. Management practices used by farmers are the cumulative result of their knowledge and perceptions of the pest and depend on access to pesticides. These knowledge and perceptions are often specific to each region [25] and influenced by many socio-economic factors, for example membership in a farmer organization [26,27].

Farmers' knowledge and management strategies for $S$. frugiperda have been poorly documented since its appearance in Africa. Thus far, the only study specifically focusing on farmers' knowledge of S. frugiperda has been carried out by Kumela et al. [28] in Kenya and Ethiopia. Their results revealed farmers' knowledge on S. frugiperda infestation, damage, and development stages. The management practices of farmers, such as the use of synthetic pesticides, plant extracts, handpicking of larvae, and application of soil to maize whorls were also reported by the same study. However, specific information regarding natural enemies, host, and repellent plants known by farmers has not been reported, though these are important for developing sustainable pest management methods. Additionally, the effectiveness of the different management practices adopted by farmers has not been addressed. The objective of the current study was to improve the understanding of the behaviour of maize farmers regarding the invasion of S. frugiperda in Benin. A national survey was carried out to assess farmers' knowledge of the pest, their perceptions, and management practices. We hypothesize that farmers could develop effective management strategies against $S$. frugiperda based on their knowledge and perceptions. This study will be useful to define the actions required for the sustainable management of S. frugiperda. 


\section{Materials and Methods}

\subsection{Study Area}

The study was conducted in 19 districts distributed in the three climatic zones of Benin: the Sudanian zone, the Sudano-Guinean zone, and the Guinean zone. Each of these zones has specific climatic characteristics (Table 1) [29].

Table 1. Characteristics of Benin's climatic zones.

\begin{tabular}{cccc}
\hline Parameters & Sudanian Zone & Sudano-Guinean Zone & Guinean Zone \\
\hline Annual rainfall range $(\mathrm{mm})$ & 1200 & $900-1110$ & $<1000$ \\
\hline Temperature range $\left({ }^{\circ} \mathrm{C}\right)$ & $25-29$ & $25-29$ & $24-31$ \\
\hline Relative humidity range $(\%)$ & $69-97$ & $31-98$ & $18-99$ \\
\hline
\end{tabular}

The choice of districts was made considering the statistics on the quantity of maize produced district published by CountrySTAT and the diagnosis of the Agricultural Development Poles carried out by the National Agricultural Research Institute of Benin (INRAB) in 2018. The location of these districts is shown in Figure 1.

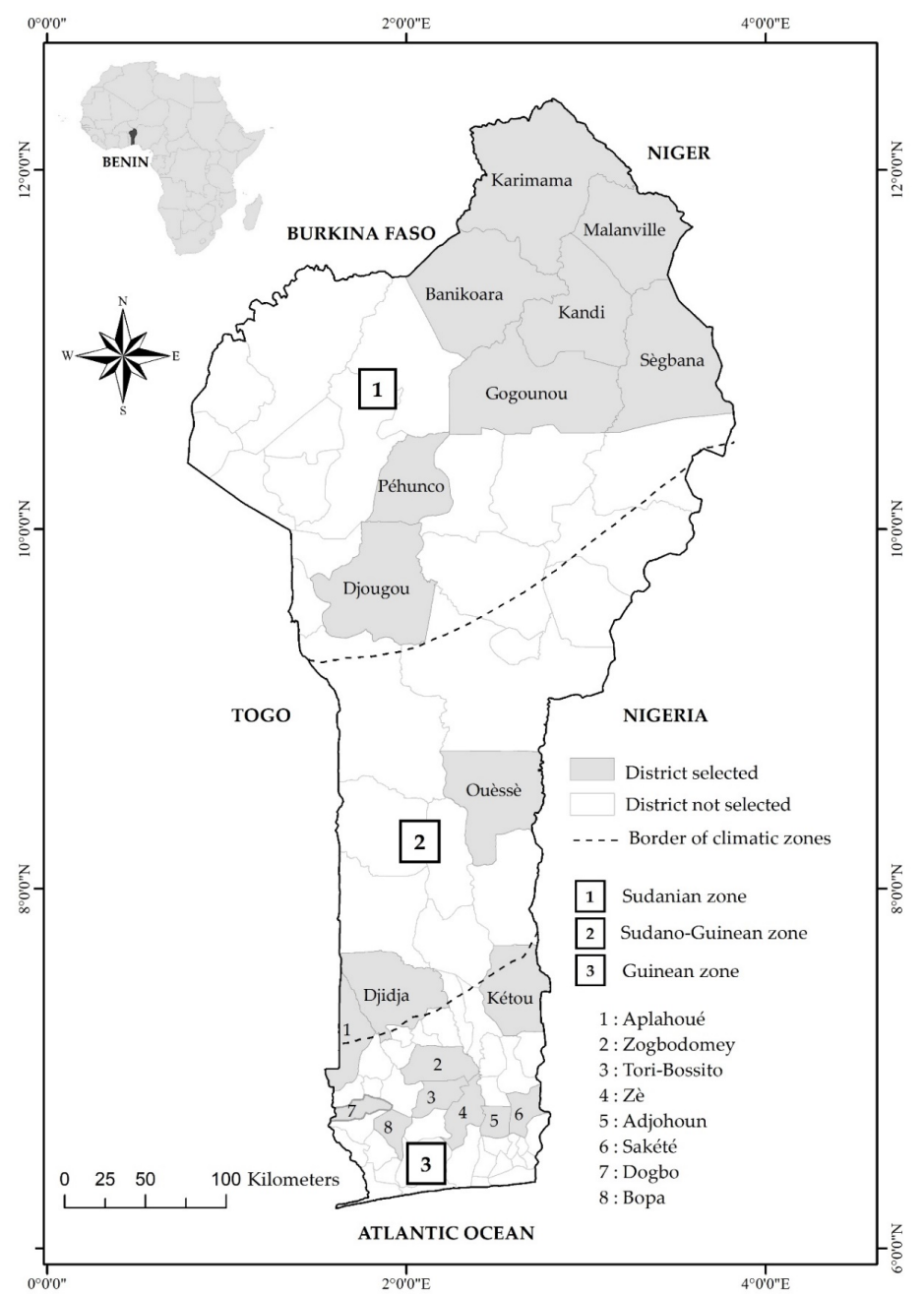

Figure 1. Map of Benin showing the location of the surveyed districts. 


\subsection{Data Collection}

In each district, two maize producing villages were randomly selected. About 33 maize farmers were face-to-face interviewed per village by surveyors using a standardized questionnaire. The final sample consisted of 1237 maize farmers. The surveys were conducted from October to December 2018. The data collected included the socio-economic profile of farmers (Table 2). In addition, data were collected on farm characteristics, knowledge, and perceptions of S. frugiperda, periods of attack, severity of damage, yield losses, trends in the spread of $S$. frugiperda attacks, farmer management practices, and their effectiveness.

Table 2. Descriptive statistics on the socio-economic profiles of the surveyed farmers.

\begin{tabular}{|c|c|c|c|}
\hline \multicolumn{2}{|r|}{ Quantitative Variables } & Means & $\begin{array}{c}\text { Standard } \\
\text { Deviations }\end{array}$ \\
\hline \multicolumn{2}{|r|}{ Age } & 41.9 & 12.3 \\
\hline \multicolumn{2}{|r|}{ Farm experience (year) } & 19.5 & 11.8 \\
\hline \multicolumn{2}{|r|}{ Household size } & 9.2 & 6.7 \\
\hline \multicolumn{2}{|r|}{ Qualitative Variables } & Numbers & Frequency $(\%)$ \\
\hline \multirow{4}{*}{ Education levels } & None & 757 & 61.2 \\
\hline & Primary & 266 & 21.5 \\
\hline & Secondary & 198 & 16.0 \\
\hline & Tertiary & 15 & 1.2 \\
\hline \multirow{7}{*}{ Main activity } & Crop production & 1144 & 92.6 \\
\hline & Livestock production & 14 & 1.1 \\
\hline & Food processing & 2 & 0.2 \\
\hline & Trade & 23 & 1.9 \\
\hline & Employee (public or private) & 9 & 0.7 \\
\hline & Crafts (e.g., sewing, hairdressing) & 22 & 1.8 \\
\hline & $\begin{array}{c}\text { Other activities (car drivers and } \\
\text { motorbike-taxi riders) }\end{array}$ & 22 & 1.8 \\
\hline \multirow{7}{*}{$\begin{array}{l}\text { Secondary } \\
\text { activities }\end{array}$} & Crop production & 92 & 8.9 \\
\hline & Livestock production & 378 & 36.5 \\
\hline & Food processing & 157 & 15.2 \\
\hline & Trade & 165 & 15.9 \\
\hline & Employee (public or private) & 16 & 1.5 \\
\hline & Crafts (e.g., sewing, hairdressing) & 78 & 7.5 \\
\hline & $\begin{array}{l}\text { Other activities (car drivers and } \\
\text { motorbike-taxi riders) }\end{array}$ & 150 & 14.5 \\
\hline & Gender (Female) & 208 & 16.8 \\
\hline \multicolumn{2}{|c|}{ Member of a farmer organization (yes) } & 433 & 35.0 \\
\hline \multicolumn{2}{|c|}{ Contact with research or extension services (yes) } & 432 & 35.1 \\
\hline \multicolumn{2}{|c|}{ Participation in pest management training (yes) } & 80 & 6.5 \\
\hline
\end{tabular}

Yield losses in this study were estimated by farmers. They compared maize yield before and after the invasion of $S$. frugiperda. To prevent farmers from confusing attacks of $S$. frugiperda with those of other maize pests, colour photographic images showing the condition of a field attacked 
by $S$. frugiperda, the stages of $S$. frugiperda development, the severity of attack and other maize pests frequently encountered in Benin were included in the questionnaire.

The Likert scale techniques [30] have been used to collect data on the management practices effectiveness among farmers who have applied at least one management practice. The Likert scale used has been labelled as follows: 1-totally ineffective, 2-ineffective, 3-relatively ineffective, 4-indifferent, 5-relatively effective, 6-effective, and 7-totally effective.

\subsection{Data Analysis}

The collected data were analysed using descriptive statistics (frequencies, means, and standard deviations). Chi-square tests were also applied to analyse the relationships between knowledge of S. frugiperda, perception of damage and socio-economic characteristics of farmers; between cropping practices (cropping systems, application of mineral fertilizers, and types of grown varieties) and severity of $S$. frugiperda attack; and between farmer protection practices and knowledge of S. frugiperda. Chi-square tests are valid when the values of the cells in the contingency table are greater than 1 and at least $80 \%$ of these values are greater than 5 [31]. Mean scores were calculated on the effective data collected.

\section{Results}

\subsection{Socio-Economic Profile of Farmers}

The surveyed farmers were mostly men $(83.2 \%)$, and their household had an average of nine people. The number of years of experience in maize production averaged 19.5 years. About $61.2 \%$ of farmers were illiterate. They practised agriculture as their main activity $(92.6 \%)$. Livestock production (e.g., poultry, goat, sheep, cattle, or pigs), food processing, and trade were their secondary activities. About $35 \%$ of them belonged to a farmer organization and had contacts with research or extension services. Six-point five percent of farmers had received training in crop pest management (Table 2).

\subsection{Farmers' Knowledge and Perceptions of S. frugiperda Attacks}

Most farmers (91.8\%) recognized the damage of S. frugiperda on maize crop. The majority $(78.9 \%)$ of them were able to identify the pest during its larval stage (Table 3). Farmers (88.6\%) observed the activities of $S$. frugiperda in their maize fields (Table 3). They recorded the first attacks of $S$. frugiperda in 2015 and 2016. They perceived S. frugiperda as a new pest. Currently, there is no name in local languages to specifically refer to $S$. frugiperda.

Table 3. Farmers' knowledge and perceptions of S. frugiperda.

\begin{tabular}{|c|c|c|c|}
\hline \multicolumn{2}{|r|}{ Variables } & Numbers & Frequency $(\%)$ \\
\hline \multicolumn{2}{|c|}{ Knowledge of $S$. frugiperda damage (Yes) } & 1136 & 91.8 \\
\hline \multirow{4}{*}{$\begin{array}{c}\text { Knowledge of } \\
\text { S. frugiperda } \\
\text { development stages }\end{array}$} & Egg (yes) & 96 & 7.8 \\
\hline & Larva (yes) & 975 & 78.9 \\
\hline & Pupa (yes) & 392 & 31.7 \\
\hline & Adult (yes) & 297 & 24.0 \\
\hline \multirow{5}{*}{$\begin{array}{l}\text { Farmer information } \\
\text { sources on S. frugiperda }\end{array}$} & Own observation in the field (yes) & 1095 & 88.6 \\
\hline & Village residents (yes) & 86 & 7.0 \\
\hline & Extension agents (yes) & 36 & 2.9 \\
\hline & Medias (radio/television) (yes) & 69 & 5.6 \\
\hline & $\begin{array}{l}\text { Residents of neighbouring localities } \\
\text { (yes) }\end{array}$ & 51 & 4.1 \\
\hline
\end{tabular}


Table 3. Cont.

\begin{tabular}{|c|c|c|c|}
\hline & Variables & Numbers & Frequency $(\%)$ \\
\hline \multirow{7}{*}{$\begin{array}{l}\text { Perception of the } \\
\text { vulnerability of maize } \\
\text { plants according to their } \\
\text { development stages }\end{array}$} & Emergence (yes) & 70 & 5.7 \\
\hline & $1 \mathrm{WAP}^{1}$ (yes) & 312 & 25.2 \\
\hline & 2 WAP (yes) & 508 & 41.1 \\
\hline & 4 WAP (yes) & 436 & 35.3 \\
\hline & 6 WAP (yes) & 307 & 24.8 \\
\hline & 8 WAP (yes) & 158 & 12.8 \\
\hline & 10 WAP (yes) & 79 & 6.4 \\
\hline \multirow{3}{*}{ Severe attack periods } & Period of light rain & 1035 & 88.2 \\
\hline & Period of heavy rain & 132 & 11.2 \\
\hline & Period of light and heavy rain & 6 & 0.5 \\
\hline \multirow{3}{*}{$\begin{array}{l}\text { Trend in the spread of } \\
\text { S. frugiperda attacks }\end{array}$} & Decrease & 161 & 13.3 \\
\hline & Stable & 85 & 7.0 \\
\hline & Increase & 963 & 79.7 \\
\hline
\end{tabular}

${ }^{1}$ Weeks After Planting (WAP). $(n=1237)$.

For most farmers, maize plants were more vulnerable from the 1st to the 4th week after planting, and attacks were more severe during periods of light rain (Table 3). The majority of farmers saw an increase in the spread of S. frugiperda attacks in 2018 compared to the previous year. About 32\% of the farmers believed that $S$. frugiperda caused more damage compared to the other maize pests they encountered in their fields (Figure 2). These include Formosan termites (Coptotermes formosanus), cob borers (Mussidia nigrivenella), maize leaf rollers (Marasmia trapezalis), grasshopper (Zonocerus variegatus), pink stalk borer (Sesamia calamistis), and corn leaf aphid (Rhopalosiphum maidis).

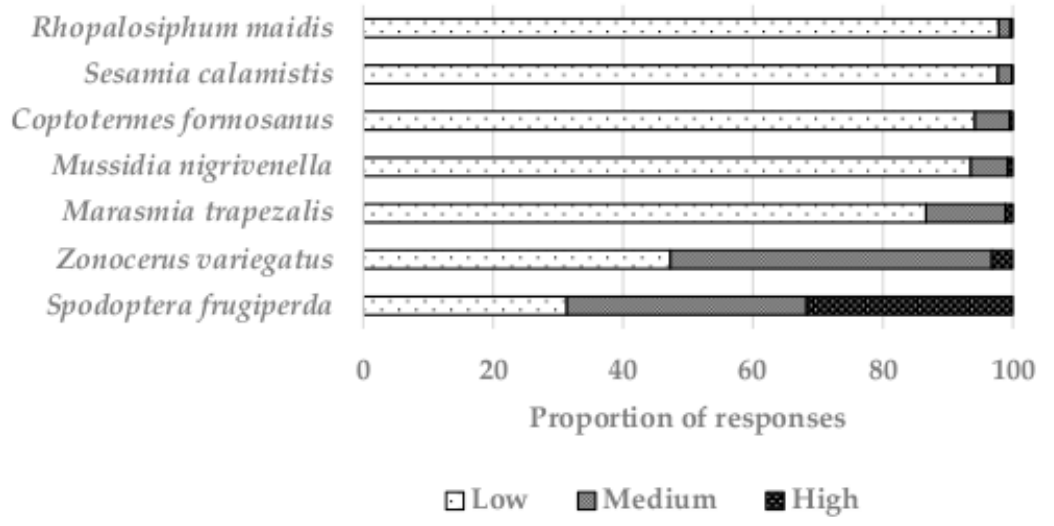

Figure 2. Farmers' perceptions of damage from maize pests.

Chi-square tests indicate that there was a relationship between farmers' knowledge and perceptions of $S$. frugiperd $a$ and their socio-economic characteristics. Farmers' knowledge of the pest was significantly associated with education level $(p=0.003)$, main activity $(p=0.006)$, membership in a farmer organization $(p=0.024)$, and contacts with research or extension services $(p=0.001)$. In addition, their perception of damage was significantly associated with membership in a farmer organization $(p=0.001)$ and contacts with research or extension services $(p=0.001)$ (Table 4$)$. 
Table 4. Chi-square analysis of the relationships between knowledge of $S$. frugiperda, perception of damage, and socio-economic characteristics of farmers.

\begin{tabular}{ccccccc}
\hline \multirow{2}{*}{ Socio-Economic Characteristics } & \multicolumn{3}{c}{ Knowledge of S. frugiperda } & \multicolumn{3}{c}{ Perception of S. frugiperda Damage } \\
\cline { 2 - 7 } & DF & $\chi^{\mathbf{2}}$ & $p$ & DF & $\chi^{2}$ & $p$ \\
\hline Education level & 3 & $13.8^{* *}$ & 0.003 & 6 & $9.7 \mathrm{~ns}$ & 0.138 \\
\hline Main activity & 6 & $17.9^{* *}$ & 0.006 & 12 & $7.0 \mathrm{~ns}$ & 0.855 \\
\hline Membership in a farmer organization & 1 & $5.1^{*}$ & 0.024 & 2 & $28.8^{* *}$ & 0.001 \\
\hline Contact with research or extension services & 1 & $16.1^{* *}$ & 0.001 & 2 & $97.7^{* *}$ & 0.001 \\
\hline
\end{tabular}

DF: Degree of Freedom; $\chi^{2}$ : Chi-square coefficient; $P$ : Probability; $: p<0.05,{ }^{* *}: p<0.01$, ns: not significant.

\subsection{Cropping Practices}

Two main cropping systems were used for maize production: single-cropping in rotation with other crops (cotton, cowpea, cassava, soybean, and groundnut) and intercropping with cassava, groundnut, cowpea, and sorghum. Overall, single-cropping was the most common cropping system (67.6\%) (Table 5). More than half of the farmers applied mineral fertilizers to the maize plants, on average $134.6 \mathrm{~kg} / \mathrm{ha}$ of NPK (Nitrogen, Phosphorus, and Potassium) and $75.4 \mathrm{~kg} / \mathrm{ha}$ of urea.

Table 5. Farmers' cropping practices.

\begin{tabular}{cccc}
\hline & Cropping Practices & Numbers & Frequency (\%) \\
\hline \multirow{2}{*}{$\begin{array}{c}\text { Maize cropping } \\
\text { systems }\end{array}$} & Intercropping & 329 & 28.1 \\
\cline { 2 - 4 } & $\begin{array}{c}\text { Single-cropping in rotation with } \\
\text { other crops }\end{array}$ & 791 & 67.6 \\
\cline { 2 - 4 } & Monocropping & 51 & 4.4 \\
\cline { 2 - 4 } $\begin{array}{c}\text { Application of } \\
\text { mineral fertilizers }\end{array}$ & No fertilizer application & 520 & 42.0 \\
\cline { 2 - 4 } & NPK & 24 & 1.9 \\
\hline \multirow{2yyy}{*}{$\begin{array}{c}\text { Types of grown } \\
\text { maize varieties }\end{array}$} & Nrea & 20 & 1.6 \\
\cline { 2 - 4 } & Traditional varieties & 673 & 54.4 \\
\cline { 2 - 4 } & Modern varieties & 710 & 38.7 \\
\hline
\end{tabular}

Traditional varieties refer to local varieties cultivated by farmers over generations while modern varieties refer to improved varieties developed by research centers. About $58.7 \%$ of the farmers grew traditional varieties of maize (Table 5). Farmers who grew modern varieties of maize used more mineral fertilizers and intercropping. In addition, farmers who grew traditional varieties of maize used fewer mineral fertilizers and practised more single-cropping in rotation with other crops.

\subsection{Damage Caused by S. frugiperda}

The results showed that around $97.1 \%$ of farmers suffered from S. frugiperda attacks in 2018. It confirms the presence of $S$. frugiperda throughout Benin, despite the geo-climatic contrasts (Table 1). About $93.9 \%$ of the maize fields were infested. The incidence of damaged maize plants per field was estimated to $58.9 \%$, and the incidence of damaged maize ears was estimated at $50.4 \%$. The estimated yield losses by farmers averaged $797.2 \mathrm{~kg} / \mathrm{ha}$ of maize in 2018 (Table 6). The farmers revealed that before the invasion of $S$. frugiperda, they obtained an average maize yield of $1626 \mathrm{~kg} / \mathrm{ha}$. Thus, the yield losses caused by $S$. frugiperda represented $49 \%$ of the average maize yield that farmers obtained before the invasion of $S$. frugiperda. 
Table 6. Indicators of damage caused by S. frugiperda according to farmers.

\begin{tabular}{|c|c|c|c|}
\hline \multicolumn{2}{|c|}{ Incidence and Maize Yield Losses } & Means & Standard Deviations \\
\hline \multicolumn{2}{|c|}{ Incidence of infested maize fields } & 93.9 & 18.1 \\
\hline \multicolumn{2}{|c|}{ Incidence of damaged plants per infested field } & 58.9 & 22.6 \\
\hline \multicolumn{2}{|c|}{ Incidence of damaged ears } & 50.4 & 20.7 \\
\hline \multicolumn{2}{|c|}{ Maize yield losses (kg/ha) } & 797.2 & 613.6 \\
\hline \multicolumn{2}{|c|}{$\begin{array}{l}\text { Damage severity for farmers who suffered from } \\
\text { S. frugiperda attacks }(n=1198)\end{array}$} & Numbers & Frequency (\%) \\
\hline \multirow{3}{*}{$\begin{array}{l}\text { Severity of } S \text {. frugiperda } \\
\text { attack on maize leaves }\end{array}$} & Low & 130 & 10.6 \\
\hline & Medium & 1003 & 81.7 \\
\hline & High & 95 & 7.7 \\
\hline \multirow{3}{*}{$\begin{array}{l}\text { Severity of S. frugiperda } \\
\text { attack on maize ears }\end{array}$} & Low & 324 & 26.6 \\
\hline & Medium & 819 & 67.1 \\
\hline & High & 77 & 6.3 \\
\hline
\end{tabular}

The analysis of the severity of $S$. frugiperda attacks was carried out by distinguishing the different parts of the attacked maize plants, in particular the leaves and ears. The majority of farmers reported that $S$. frugiperda attacks were moderately severe on the leaves and ears (Table 6). At the time of the attack, they found large elongated perforations on the leaves, whorl attack and damage ranging from 15 to $25 \%$ of maize grains.

Chi-square tests showed that there was a relationship between the severity of $S$. frugiperda attack and the types of grown maize varieties. The severity of $S$. frugiperda attack on the leaves and ears was significantly associated with types of grown maize varieties $(p=0.001)$. S. frugiperda attacks were more severe for modern varieties of maize. There was no significant relationship between the cropping systems, application of mineral fertilizers, and attack severity (Table 7).

Table 7. Chi-square test analysis of the relationship between cropping practices and the severity of S. frugiperda damage.

\begin{tabular}{ccccccc}
\hline \multirow{2}{*}{ Cropping Practices } & \multicolumn{2}{c}{ Severity of S. frugiperda Attack on the Leaves } & \multicolumn{3}{c}{ Severity of S. frugiperda Attack on the Ears } \\
\cline { 2 - 6 } & DF & $\chi^{2}$ & $p$ & DF & $\chi^{2}$ & \multicolumn{1}{c}{$p$} \\
\hline Maize cropping systems & 4 & $8.1 \mathrm{~ns}$ & 0.088 & 4 & 0.176 \\
\hline Types of grown maize varieties & 4 & $165.0^{* *}$ & 0.001 & 4 & $173.7^{* *}$ \\
\hline Application of mineral fertilizers & 6 & $7.5 \mathrm{~ns}$ & 0.275 & 6 & $10.4 \mathrm{~ns}$ & 0.110 \\
\hline
\end{tabular}

DF: Degree of Freedom; $\chi^{2}$ : Chi-square value; $p$ : Probability; **: $p<0.01$, ns: not significant.

\subsection{Knowledge of Natural Enemies, Host and Repellent Plants of S. frugiperda}

About $16 \%$ of farmers stated knowing insects and birds that feed on S. frugiperda larvae. They identified the francolin (Francolinus bicalcaratus), the village weaver (Ploceus cucullatus), and the common wasp (Vespula vulgaris) as natural enemies of S. frugiperda. For $14 \%$ of farmers, S. frugiperda could destroy other crops besides maize. They said the pest could damage sorghum, cotton, cowpea, and tomato crops.

In addition, about $5 \%$ of farmers stated knowing plants that repel S. frugiperda. They identified yellow nutsedge (Cyperus esculentus), chan (Hyptis suaveolens), shea tree (Vitellaria paradoxa), neem (Azadirachta indica), tamarind (Tamarindus indica), and soybean (Glycine max) as repellent plants of S. frugiperda. 


\subsection{Farmers' Management Practices}

About $38 \%$ of the farmers surveyed used at least one control practice. The most common management method used by farmers was synthetic pesticides. Among farmers using at least one management method, $91.4 \%$ used synthetic pesticides, $1.9 \%$ used botanical pesticides, and $6.6 \%$ used other management practices. The wide range of synthetic pesticides used by farmers included Thalis 112 EC (emamectin benzoate and acetamiprid), Pyro FTE 472 (cypermethrin and chlorpyriphos-ethyl), Pacha 25 EC (lambda-cyhalothrin and acetamiprid), Lambda super 2.5 EC (lambda-cyhalothrin), and Emacot 019 EC (emamectin benzoate) (Table 8).

Table 8. Management practices used by farmers.

\begin{tabular}{cccc}
\hline Management Practices Used & Numbers & Frequency (\%) & Average Effectiveness Score \\
\hline Synthetic pesticides & 428 & 91.4 & 5 \\
\hline Thalis 112 EC & 193 & 45.1 & 5 \\
\hline Pyro FTE 472 & 41 & 9.6 & 4 \\
\hline Pacha 25 EC & 67 & 15.7 & 4 \\
\hline Lambda super 2.5 EC & 42 & 9.8 & 4 \\
\hline Emacot 019 EC & 29 & 6.8 & 6 \\
\hline Botanical pesticides & 9 & 1.9 & 3 \\
\hline Other practices & 31 & 6.6 &
\end{tabular}

The average effectiveness score for all of these synthetic pesticides is 5 out of 7 . Thus, farmers believed that synthetic pesticides were relatively effective against $S$. frugiperda. Among the synthetic pesticides, Emacot 019 EC is the one for which the average effectiveness score is 6 followed by Thalis 112 EC whose score is 5 (Table 8).

The botanical pesticides used by farmers against $S$. frugiperda were usually made from neem leaves or seeds (Azadirachta indica), vernonia leaves (Vernonia amygdalina), pepper (Capsicum annuum), and ashes. Some farmers also added other raw materials such as soap, detergents, or petroleum to botanical pesticides. The average effectiveness score for all botanical pesticides is 6 and indicates that the botanical pesticides were effective against $S$. frugiperda.

Moreover, some farmers used other practices to manage $S$. frugiperda $(7 \%)$. These included early planting, handpicking larvae, and the application of ash to the whorls of maize. The average effectiveness score for these practices is 3 and indicates that they were relatively ineffective against S. frugiperda.

Chi-square tests showed that there was a relationship between knowledge of the pest and the use of management practices $(p=0.001)$ and between knowledge of the pest and the types of management practices used ( $p=0.002$ ) (Table 9$)$. This result confirms that the implementation of management strategies by farmers was associated with their knowledge of the pest. The Chi-square tests also showed that the use of management practices by farmers and the type of management practices used were significantly associated with membership in a farmer organization and contact with research or extension services (Table 9). 
Table 9. Chi-square test analysis of the relationships between farmers' management practices, knowledge, perceptions, and socio-economic characteristics.

\begin{tabular}{cccccccc}
\hline \multirow{2}{*}{ Socio-Economic Characteristics } & \multicolumn{3}{c}{ Use of Management Practices } & \multicolumn{3}{c}{ Type of Management Practices } \\
\cline { 2 - 7 } & DF & $\chi^{2}$ & $p$ & DF & $\chi^{2}$ & $p$ \\
\hline Knowledge of S. frugiperda & 1 & $24.7^{* *}$ & 0.001 & 2 & $12.3^{* *}$ & 0.002 \\
\hline Perception of S. frugiperda damage & 2 & $67.3^{* *}$ & 0.001 & 4 & $5.6 \mathrm{~ns}$ & 0.234 \\
\hline Education levels & 3 & $4.4 \mathrm{~ns}$ & 0.218 & 6 & $2.2 \mathrm{~ns}$ & 0.903 \\
\hline Main activity & 6 & $7.1 \mathrm{~ns}$ & 0.312 & 10 & $9.8 \mathrm{~ns}$ & 0.457 \\
\hline Membership in a farmer organization & 1 & $41.1^{* *}$ & 0.001 & 2 & $6.1^{*}$ & 0.047 \\
\hline $\begin{array}{c}\text { Contact with research or extension } \\
\text { services }\end{array}$ & 1 & $41.9^{* *}$ & 0.001 & 2 & $7.2^{*}$ & 0.027 \\
\hline
\end{tabular}

DF: Degree of Freedom; $\chi^{2}$ : Chi-square coefficient; $p$ : Probability; ${ }^{*}: p<0.05,{ }^{* *}: p<0.01$, ns: not significant.

\section{Discussion}

\subsection{Farmers' Knowledge and Perceptions of S. frugiperda Attacks}

In this study, most maize farmers recognized the damage of $S$. frugiperda and were able to identify it at its larval stage. Some farmers ( 7.8 to $31.7 \%$ ) were able to identify other development stages of S. frugiperda, including eggs, pupae, and adults. The identification of these development stages requires a better knowledge of the biology of the pest [4].

The first attack of S. frugiperda was recorded in 2015 by some farmers. According to Goergen et al. [2], the attacks of S. frugiperda were first reported in West and Central Africa in early 2016. From farmers' perception, it could be inferred that $S$. frugiperda was present in Benin before 2016, but its damage became significant from 2016.

As well, the study showed that farmers' knowledge and perceptions of S. frugiperda were associated with their membership in a farmer organization and their contact with research or extension services. Therefore, the institutional environment of farmers could play a crucial role in the sustainable management of $S$. frugiperda.

\subsection{Damage Caused by S. frugiperda}

S. frugiperda was present throughout Benin despite the geo-climatic contrasts. The life cycle of the pest lasts, on average, 30 days and the optimal temperatures for adults and larvae are $25^{\circ} \mathrm{C}$ and $30^{\circ} \mathrm{C}$ respectively [32]. In Benin, the temperature varies between 24 and $31^{\circ} \mathrm{C}$ depending on the climatic zones [29]. Thus, the country offers favourable climatic conditions for the permanent reproduction of this pest.

Yield losses caused by S. frugiperda averaged $797 \mathrm{~kg}$ of maize per hectare, or $49 \%$ of the average maize yield obtained by farmers before the invasion of $S$. frugiperda. This result corroborates forecasts by the Centre for Agriculture and Bioscience International (CABI), indicating that $S$. frugiperda could cause a loss of $40 \%$ of the average annual maize production in Benin [33]. In Kenya and Ethiopia, yield losses were greater. They ranged from 0.8 to 1 ton of maize per ha [28]. The differences in yield losses between countries could be explained by the levels of infestation which may depend on climatic factors, management practices used by farmers and insecticide availabilities. In Nicaragua, Hruska and Gould [34] demonstrated a positive relationship between yield losses and levels of S. frugiperda infestation. For them, infestations of 55 to $100 \%$ of maize plants could cause yield losses ranging from 15 to $73 \%$.

The severity of the pest attacks was not significantly associated with cropping systems. Andrews [35] showed that intercropping was less severely attacked by S. frugiperda than monocropping and that intercropping could reduce damage by up to 30\%. Furthermore, Baudron et al. [36] demonstrated that frequent weeding and no-till sowing reduced the damage of $S$. frugiperda. As well, yield losses due to $S$. frugiperda attacks have been shown to vary with planting dates. Some farmers 
in Kenya reported significant yield losses on late-planted maize plots compared to plots planted earlier [3].

Moreover, the severity of $S$. frugiperda attack was associated with the types of grown maize varieties. The attacks were more severe for modern varieties than traditional varieties. This means that the modern varieties used in Benin were not resistant to $S$. frugiperda attacks. Some papers reported that yield loss of modern varieties due to $S$. frugiperda was not significant when they received adequate fertilizers or when they were planted on rich soils $[36,37]$. Certainly in this research, farmers lacked in supplying enough fertilizers that may reinforce modern varieties defense against $S$. frugiperda. The perception of farmers about the resistance of traditional varieties to $S$. frugiperda suggests that these varieties may contain resistant genes that need to be investigated. In terms of management strategies, increasing the diversification of varieties could be one of the means of effective management of $S$. frugiperda, in addition to identify the resistance traits of traditional varieties and breed them into modern varieties.

\subsection{Farmers' Knowledge of Natural Enemies and Host Plants of S. frugiperda}

Some farmers identified the francolin, the village weaver, and the common wasp as natural enemies of $S$. frugiperda. The francolin and the village weaver are known in the literature as bird species that feed on a wide variety of plants and insects. Thus, they could truly be natural enemies of S. frugiperda. However, they are classified as the main grain-eating birds in maize field [38]. In general, insectivorous birds play an important role in reducing pest abundance in various agro-ecological systems. Some bird species may be able to extract S. frugiperda larvae from whorls and husks [39]. These birds are able to cause significant additional damage to plants [38]. Regarding the natural enemy function of the common wasp, studies confirm the perception of farmers. In a study in Brazil, wasps picked an average of 1.54 larvae per colony per hour and predated $77 \%$ of $S$. frugiperda present in maize plots ( 1 colony per $25 \mathrm{~m}^{2}$ ), providing effective control [39].

Other natural enemies of $S$. frugiperda have been recorded in West Africa. In Benin and Ghana, ten species were found parasitizing S. frugiperda among which two egg parasitoids (Telenomus remus Dixon and Trichogramma sp.), one egg-larval (Chelonus bifoveolatus Szépligeti), five larval (Coccygidium luteum (Brullé), Cotesia icipe Fernandez-Triana and Fiaboe, Charops sp., Pristomerus pallidus (Kriechbaumer) and Drino quadrizonula (Thomson)), and two larval-pupal parasitoids (Meteoridea cf. testacea (Granger) and Metopius discolor Tosquinet) [40]. Three predator species, namely Pheidole megacephala (F.), Haematochares obscuripennis Stål and Peprius nodulipes (Signoret), were recorded in Ghana [41].

As well, some farmers reported pest attacks in the sorghum, cotton, cowpea, and tomato fields. All these crops are among the 353 host plants of $S$. frugiperda larvae inventoried in Brazil [5].

\subsection{Farmers' Knowledge of Repellent Plants of S. frugiperda}

Farmers identified yellow nutsedge, chan, shea tree, neem, tamarind, and soybean as repellent plants of $S$. frugiperda through their experiments. They considered that the presence of these plants near or in the maize fields coincided with the low infestations of S. frugiperda. Some of these plants may act as a trap plant as a push pull system [4]. Peruca et al. [42] studied the harmful effects of soybean plants on S. frugiperda. They confirm that soybean plants could activate chemical defence mechanisms that alter the developmental cycle of $S$. frugiperda, suggesting effective cultural control options. Several other studies showed the effectiveness of neem extracts against $S$. frugiperda. Magrini et al. [43] concluded that neem derivatives had potent and adverse antifeedant effects on all stages of larval development of S. frugiperda. Tavares et al. [44] recommended neem oil to manage $S$. frugiperda due to its high toxicity. Zuleta-Castro et al. [45] formulated a botanical product active against $S$. frugiperda using neem extracts. Adeye et al. [46] found that neem oil at $4.51 . \mathrm{ha}^{-1}$ reduced the incidence of pest attacks, the severity of damage and the loss of maize yield by $42.8 \%$ and $57.0 \%$. Regarding the other repellent plants identified by farmers (yellow nutsedge, chan, shea, and tamarind), future studies should be carried out to evaluate the accuracy of farmers' perception. 


\subsection{Farmers' Management Practices}

Most farmers in Benin used synthetic pesticides to manage S. frugiperda. The same was observed in other African countries such as Ghana, Zambia, Nigeria, Kenya, and Ethiopia [7,28,47]. Synthetic pesticides are indeed easily accessible for farmers. Institutions like USAID and other organizations such as FAO advocate low use of synthetic pesticides. However, there is no evidence that farmers comply with the recommendations of these organizations which advocate the rational and threshold use of synthetic pesticides. This implies that an effort remains to be deployed by the extension services concerning the use of synthetic pesticides against $S$. frugiperda.

In Benin, farmers found that chemical control was relatively effective. Farmers' perceptions of the effectiveness of chemical control differ from country to country. For example, in Kenya about $60 \%$ of farmers found synthetic pesticides ineffective, while Ethiopian farmers claimed that chemical control was effective against $S$. frugiperda [28].

Some farmers who used botanical pesticides thought they were more effective than synthetic pesticides against $S$. frugiperda. However, these botanical pesticides were little used. This could be explained by the lack of knowledge on the raw materials and the manufacturing process. The botanical pesticides used by farmers against $S$. frugiperda were usually made from neem leaves or seeds, vernonia leaves, pepper, and ash. Some of the farmers also added soaps, detergents, or petroleum to botanical pesticides. Vernonia is one of the African pesticidal plants selected to improve botanical-based pest management in smallholder agriculture in Africa [48]. However, its effectiveness against S. frugiperda has not yet been studied. It is the same with pepper, ashes, soaps, detergents, and petroleum. It is up to agricultural research institutions and scientists to refine and standardize botanical pesticides made by farmers for their scaling up.

The results showed that farmers' management practices were significantly associated with their knowledge of the pest and their socio-economic characteristics such as membership of a farmer organization and contact with research or extension services. It is inferred that farmers' management practices are the result of their knowledge of the pest. Farmer organizations and extension services have the potential to improve farmers' knowledge and induce behavioural changes in their pest management strategies [49], and thus influence their pest management decisions. As more than half of the farmers surveyed were uneducated, extension services should consider disseminating relevant information in the local language and doing demonstrations directly in the fields to improve farmers' knowledge and pest management skills.

\section{Conclusions}

This paper reported on farmers' knowledge, their perceptions, and management practices they use against Spodoptera frugiperda. The majority of farmers use synthetic pesticides which do not always satisfy them in the management of $S$. frugiperda. A minority use local practices which seem more effective according to their perceptions. These essentially ecological local practices deserve to be studied and scaled up. The study showed that there was a relationship between knowledge of S. frugiperda and the use of management practices. There was also a relationship between knowledge of the pest and types of management practices. Therefore, the study confirms that farmers' knowledge of the pest is an important factor that influences their decision to manage the pest. Further research is required to refine and standardize management practices deemed effective by farmers and to analyse farmers' willingness to pay for improved management practices.

Author Contributions: Conceptualization, S.H., A.Z., A.A. (Augustin Aoudji), H.C.S., A.S., R.S., E.Z., H.S.T.V., A.A. (Aristide Adomou) and A.A.(Adam Ahanchédé); methodology, S.H., A.Z., A.A. (Augustin Aoudji) and H.C.S.; formal analysis, S.H. and A.Z.; investigation, S.H.; writing-original draft preparation, S.H. and A.Z.; writing-review and editing, A.Z., A.A. (Augustin Aoudji), H.C.S., A.S., R.S., E.Z., H.S.T.V., A.A. (Aristide Adomou) and A.A. (Adam Ahanchédé); supervision, A.Z., A.A. (Augustin Aoudji), H.C.S., A.S., R.S., E.Z., H.S.T.V., A.A. (Aristide Adomou) and A.A. (Adam Ahanchédé); funding acquisition, UAC and INRAB. All authors read and agreed to the published version of the manuscript. 
Funding: This research was funded by the SPODOBEN Project under grant PFCR III 2018-2020 of the University of Abomey-Calavi (UAC), Benin and the National Institute of Agricultural Research of Benin (INRAB) under grant SE06-2018.

Acknowledgments: The authors thank the farmers for providing useful information.

Conflicts of Interest: The authors declare no conflict of interest.

\section{References}

1. Food and Agriculture Organization of the United Nations. Note d'information de la FAO sur la Chenille Légionnaire d'automne en Afrique; FAO: Rome, Italy, 2017; pp. 1-2. (In French)

2. Goergen, G.; Kumar, P.L.; Sankung, S.B.; Togola, A.; Tamò, M. First report of outbreaks of the fall armyworm Spodoptera frugiperda (J E Smith) (Lepidoptera, Noctuidae), a new alien invasive pest in West and Central Africa. PLoS ONE 2016, 11, e0165632. [CrossRef]

3. Food and Agriculture Organization of the United Nations. Integrated Management of the Fall Armyworm on Maize: A Guide for Farmer Field Schools in Africa; FAO: Rome, Italy, 2018; ISBN 978-92-5-130493-8.

4. Prasanna, B.M.; Huesing, J.E.; Eddy, R.; Peschke, V.M. Fall Armyworm in Africa: A Guide for Integrated Pest Management, 3rd ed.; CIMMYT: Mexico City, Mexico, 2018; pp. 11-106.

5. Montezano, D.G.; Specht, A.; Gómez, D.R.S.; Roque-Specht, V.F.; Sousa-Silva, J.; Paula-Moraes, S.; Peterson, J.A.; Hunt, T. Host Plants of Spodoptera frugiperda (Lepidoptera: Noctuidae) in the Americas. Afr. Èntomol. 2018, 26, 286-300. [CrossRef]

6. Ministère de l'Agriculture, de l'Elevage et de la Pêche. Visites des Zones Maïsicoles de la Vallée de Ouémé: Etat des Lieux des Attaques de la Chenille Légionnaire Spodoptera frugiperda et Mesures Prises par les Producteurs; MAEP: Cotonou, Bénin, 2016; pp. 1-32. (In French)

7. Abrahams, P.; Beale, T.; Cock, M.; Corniani, N.; Day, R.; Godwin, J.; Murphy, S.; Richards, G.; Vos, J. Impacts and control options in Africa: Preliminary Evidence Note; University of Exeter: Exeter, England, 2017; pp. 1-18.

8. Pitre, N.H. Chemical control of the fall armyworm (Lepidoptera: Noctuidae): An update. Fla. Entomol. 1986, 69, 570-578. [CrossRef]

9. Yu, S.J. Insecticide resistance in the fall armyworm, Spodoptera frugiperda (J. E. Smith). Pestic. Biochem. Physiol. 1991, 39, 84-91. [CrossRef]

10. Farias, J.R.; Andow, D.A.; Horikoshi, R.J.; Sorgatto, R.J.; Fresia, P.; dos Santos, A.C.; Omoto, C. Field-evolved resistance to Cry1F maize by Spodoptera frugiperda (Lepidoptera: Noctuidae) in Brazil. Crop. Prot. 2014, 64, 150-158. [CrossRef]

11. Bernardi, D.; Salmeron, E.; Horikoshi, R.J.; Bernardi, O.; Dourado, P.M.; Carvalho, R.A.; Martinelli, S.; Head, G.P.; Omoto, C. Cross-Resistance between Cry1 Proteins in Fall Armyworm (Spodoptera frugiperda) May Affect the Durability of Current Pyramided Bt Maize Hybrids in Brazil. PLoS ONE 2015, 10, e0140130. [CrossRef]

12. Miraldo, L.L.; Bernardi, O.; Horikoshi, R.J.; e Amaral, F.S.A.; Bernardi, D.; Omoto, C. Functional dominance of different aged larvae of Bt-resistant Spodoptera frugiperda (Lepidoptera: Noctuidae) on transgenic maize expressing Vip3Aa20 protein. Crop. Prot. 2016, 88, 65-71. [CrossRef]

13. Bernardi, D.; Bernardi, O.; Horikoshi, R.J.; Salmeron, E.; Okuma, D.M.; Farias, J.R.; do Nascimento, A.R.B.; Omoto, C. Selection and characterization of Spodoptera frugiperda (Lepidoptera: Noctuidae) resistance to MON $89034 \times$ TC1507 × NK603 maize technology. Crop. Prot. 2017, 94, 64-68. [CrossRef]

14. Joshi, R.C.; Matchoc, O.R.O.; Bahatan, R.G.; Pena, F.A.D. Farmers' knowledge, attitudes and practices of rice crop and pest management at Ifugao Rice Terraces, Philippines. Int. J. Pest. Manag. 2000, 46, 43-48. [CrossRef]

15. Obopile, M.; Munthali, D.C.; Matilo, B. Farmers' knowledge, perceptions and management of vegetable pests and diseases in Botswana. Crop. Prot. 2008, 27, 1220-1224. [CrossRef]

16. Mendesil, E.; Shumeta, Z.; Anderson, P.; Rämert, B. Smallholder farmers' knowledge, perceptions and management of pea weevil in north and north-western Ethiopia. Crop. Prot. 2016, 81, 30-37. [CrossRef]

17. Allahyari, M.S.; Damalas, C.A.; Ebadattalab, M. Farmers' Technical Knowledge about Integrated Pest Management (IPM) in Olive Production. Agriculture 2017, 7, 101. [CrossRef]

18. Van Mele, P.V.; Cuc, N.T.T.; Huis, A.V. Farmers' knowledge, perceptions and practices in mango pest management in the Mekong Delta, Vietnam. Int. J. Pest. Manag. 2001, 47, 7-16. [CrossRef] 
19. Vissoh, P.V. Participatory Development of Weed Management Technologies in Benin; Tropical resource Management Papers; Wageningen University: Wageningen, The Netherlands, 2006; ISBN 978-90-8585-100-4.

20. Yang, P.; Iles, M.; Yan, S.; Jolliffe, F. Farmers' knowledge, perceptions and practices in transgenic Bt cotton in small producer systems in Northern China. Crop. Prot. 2005, 24, 229-239. [CrossRef]

21. Zannou, A. Socio-Economic, Agronomic and Molecular Analysis of Yam and Cowpea Diversity in the Guinea-Sudan Transition Zone of Benin. Ph.D. Thesis, Wageningen University, Wageningen, The Netherlands, 2006.

22. Kuramoto, J.; Sagasti, F. Integrating Local and Global Knowledge, Technology and Production Systems: Challenges for Technical Cooperation. Sci. Technol. Soc. 2002, 7, 215-247. [CrossRef]

23. Chiffoleau, Y.; Desclaux, D. Participatory plant breeding: The best way to breed for sustainable agriculture? Int. J. Agric. Sustain. 2006, 4, 119-130. [CrossRef]

24. Schreinemachers, P.; Balasubramaniam, S.; Boopathi, N.M.; Ha, C.V.; Kenyon, L.; Praneetvatakul, S.; Sirijinda, A.; Le, N.T.; Srinivasan, R.; Wu, M.-H. Farmers' perceptions and management of plant viruses in vegetables and legumes in tropical and subtropical Asia. Crop. Prot. 2015, 75, 115-123. [CrossRef]

25. Trutmann, P.; Voss, J.; Fairhead, J. Local knowledge and farmer perceptions of bean diseases in the central African highlands. Agric. Hum. Values 1996, 13, 64-70. [CrossRef]

26. Midega, C.A.O.; Nyang'au, I.M.; Pittchar, J.; Birkett, M.A.; Pickett, J.A.; Borges, M.; Khan, Z.R. Farmers' perceptions of cotton pests and their management in western Kenya. Crop. Prot. 2012, 42, 193-201. [CrossRef]

27. Khan, Z.R.; Midega, C.A.O.; Nyang'au, I.M.; Murage, A.; Pittchar, J.; Agutu, L.O.; Amudavi, D.M.; Pickett, J.A. Farmers' knowledge and perceptions of the stunting disease of Napier grass in Western Kenya. Plant. Pathol. 2014, 63, 1426-1435. [CrossRef]

28. Kumela, T.; Simiyu, J.; Sisay, B.; Likhayo, P.; Mendesil, E.; Gohole, L.; Tefera, T. Farmers' knowledge, perceptions, and management practices of the new invasive pest, fall armyworm (Spodoptera frugiperda) in Ethiopia and Kenya. Int. J. Pest. Manag. 2019, 65, 1-9. [CrossRef]

29. Mensah, S.; Houehanou, T.D.; Sogbohossou, E.A.; Assogbadjo, A.E.; Glèlè Kakaï, R. Effect of human disturbance and climatic variability on the population structure of Afzelia africana Sm. ex pers. (Fabaceae-Caesalpinioideae) at country broad-scale (Bénin, West Africa). S. Afr. J. Bot. 2014, 95, 165-173. [CrossRef]

30. Rutsaert, P.; Pieniak, Z.; Regan, Á.; McConnon, Á.; Verbeke, W. Consumer interest in receiving information through social media about the risks of pesticide residues. Food Control. 2013, 34, 386-392. [CrossRef]

31. Glèlè Kakaï, R.; Lykke, A.M. Aperçu sur les méthodes statistiques univariées utilisées dans les études de végétation. Ann. Sci. Agron. 2016, 20, 113-138. (In French)

32. Capinera, J.L. Fall Armyworm, Spodoptera frugiperda (J.E. Smith) (Insecta: Lepidoptera: Noctuidae); UF/IFAS Extension: Gainesville, FL, USA, 2017; pp. 1-6.

33. Day, R.; Abrahams, P.; Bateman, M.; Beale, T.; Clottey, V.; Cock, M.; Colmenarez, Y.; Corniani, N.; Early, R.; Godwin, J.; et al. Fall Armyworm: Impacts and Implications for Africa. Outlooks Pest. Manag. 2017, 28, 196-201. [CrossRef]

34. Hruska, A.J.; Gould, F. Fall Armyworm (Lepidoptera: Noctuidae) and Diatraea lineolata (Lepidoptera: Pyralidae): Impact of larval population level and temporal occurrence on maize yield in Nicaragua. J. Econ. Entomol. 1997, 90, 611-622. [CrossRef]

35. Andrews, K.L. Latin American Research on Spodoptera frugiperda (Lepidoptera: Noctuidae). Fla. Entomol. 1988, 71, 630-653. [CrossRef]

36. Baudron, F.; Zaman-Allah, M.A.; Chaipa, I.; Chari, N.; Chinwada, P. Understanding the factors influencing fall armyworm (Spodoptera frugiperda J.E. Smith) damage in African smallholder maize fields and quantifying its impact on yield. A case study in Eastern Zimbabwe. Crop. Prot. 2019, 120, 141-150. [CrossRef]

37. Kansiime, K.M.; Mugambi, I.; Rwomushana, I.; Nunda, W.; Lamontagne-Godwin, J.; Rware, H.; Phiri, A.N.; Chipabika, G.; Ndlovud, M.; Daya, R. Farmer perception of fall armyworm (Spodoptera frugiperda J.E. Smith) and farm-level management practices in Zambia. Pest. Manag. Sci. 2019, 75, 2840-2850. [CrossRef]

38. Sikirou, R.; Nakouzi, S.; Adanguidi, J.; Bahama, J. Reconnaissance des Ravageurs du maïs en Culture au Bénin et Méthodes de lute-Fiche Technique; FAO: Cotonou, Benin, 2018; pp. 7-28.

39. Harrison, R.D.; Thierfelder, C.; Baudron, F.; Chinwada, P.; Midega, C.; Schaffner, U.; van den Berg, J. Agro-ecological options for fall armyworm (Spodoptera frugiperda JE Smith) management: Providing low-cost, smallholder friendly solutions to an invasive pest. J. Environ. Manag. 2019, 243, 318-330. [CrossRef] 
40. Agboyi, K.L.; Goergen, G.; Beseh, P.; Mensah, A.S.; Clottey, A.V.; Glikpo, R.; Buddie, A.; Cafà, G.; Offord, L.; Day, R.; et al. Parasitoid Complex of Fall Armyworm, Spodoptera frugiperda, in Ghana and Benin. Insects 2020, 11, 68. [CrossRef] [PubMed]

41. Koffi, D.; Kyerematen, R.; Eziah, Y.V.; Agboka, K.; Adom, M.; Goergen, G.; Meagher, L.R., Jr. Natural enemies of the fall armyworm, Spodoptera frugiperda (J.E. Smith) (Lepidoptera: Noctuidae) in Ghana. Fla. Entomol. 2020, 103, 85-90. [CrossRef]

42. Peruca, R.D.; Coelho, R.G.; da Silva, G.G.; Pistori, H.; Ravaglia, L.M.; Roel, A.R.; Alcantara, G.B. Impacts of soybean-induced defenses on Spodoptera frugiperda (Lepidoptera: Noctuidae) development. Arthropod-Plant Interact. 2018, 12, 257-266. [CrossRef]

43. Magrini, F.E.; Specht, A.; Gaio, J.; Girelli, C.P.; Migues, I.; Heinzen, H.; Saldaña, J.; Sartori, V.C.; Cesio, V. Antifeedant activity and effects of fruits and seeds extracts of Cabralea canjerana canjerana (Vell.) Mart. (Meliaceae) on the immature stages of the fall armyworm Spodoptera frugiperda (JE Smith) (Lepidoptera: Noctuidae). Ind. Crops Prod. 2015, 65, 150-158. [CrossRef]

44. Tavares, W.S.; Costa, M.A.; Cruz, I.; Silveira, R.D.; Serrão, J.E.; Zanuncio, J.C. Selective effects of natural and synthetic insecticides on mortality of Spodoptera frugiperda (Lepidoptera: Noctuidae) and its predator Eriopis connexa (Coleoptera: Coccinellidae). J. Environ. Sci. Health B 2010, 45, 557-561. [CrossRef] [PubMed]

45. Zuleta-Castro, C.; Rios, D.; Hoyos, R.; Orozco-Sánchez, F. First formulation of a botanical active substance extracted from neem cell culture for controlling the armyworm. Agron. Sustain. Dev. 2017, 37, 40. [CrossRef]

46. Adeye, A.T.; Sikirou, R.; Boukari, S.; Aboudou, M.; Amagnide, G.Y.G.A.; Idrissou, B.S.; Drissou-Toure, M.; Zocli, B. Protection de la culture de maïs contre Spodoptera frugiperda avec les insecticides plantneem, lambdace 25 EC et viper 46 EC et reduction de pertes de rendement au Benin. J. Rech. Sci. Univ. Lomé 2018, 20, $53-65$. [CrossRef]

47. Togola, A.; Meseka, S.; Menkir, A.; Badu-Apraku, B.; Boukar, O.; Tamò, M.; Djouaka, R. Measurement of Pesticide Residues from Chemical Control of the Invasive Spodoptera frugiperda (Lepidoptera: Noctuidae) in a Maize Experimental Field in Mokwa, Nigeria. Int. J. Environ. Res. Public Health 2018, 15, 849. [CrossRef]

48. Stevenson, P.C.; Isman, M.B.; Belmain, S.R. Pesticidal plants in Africa: A global vision of new biological control products from local uses. Ind. Crops Prod. 2017, 110, 2-9. [CrossRef]

49. Tambo, J.A.; Aliamo, C.; Davis, T.; Mugambi, I.; Romney, D.; Onyango, D.O.; Kansiime, M.; Alokit, C.; Byantwale, S.T. The impact of ICT-enabled extension campaign on farmers' knowledge and management of fall armyworm in Uganda. PLoS ONE 2019, 14, e0220844. [CrossRef] 